\title{
COURT RULINGS IMPACT ON ELECTRONIC COMMUNICATIONS LAW SYSTEMATIZATION
}

Purpose. The paper reveals the directions of using legal positions of court rulings to systematize the electronic communications law regarding consolidation of legal regulations within the national legal framework of Ukraine, taking into account supranational practice of legal support of the electronic communications market participants.

Methods. For achievement of research purposes, the author uses special legal methods of scientific knowledge: formal-logical, system-functional, comparative-legal.

Results. In the first part of the paper, the author deals with the place of the court rulings in the system of sources, according to which the consolidation of the electronic communications law provisions is to be carried out. Taking into account the latest doctrinal approaches, the "truncated" quality of such sources of law is specified. The author gives examples of how the Supreme Court's legal position concerns the definition of the legal limits for the public administration to use tools in relation to the electronic communications, operation of radio frequency and number resources of Ukraine, etc.

The second part of the paper highlights that the provisions of the European Court of Human Rights practice might affect the electronic communications law not only to determine the essence of certain types of sources of the law, the system of the electronic communications law, but also on the implementation of legal regulations in this area. Role of the European Court of Human Rights practice has been demonstrated as to systematize the electronic communications law in the context of dogmatic legal regulations.

Conclusions. Firstly, on the basis of the analysis of the European and national court rulings, the author concludes that it is expedient to implement the legal positions of the judicial authorities that will promote the institutionalization of the rule of law principle in the functioning of the electronic communications market. Secondly, it has been proved that the Supreme Court's rulings might contain conclusions on the further practice of dealing with similar cases. Generalization of practice, explanations and guidance of the Plenum is an overhead structure that defines judicial practice in the lower courts with a view to resolving conflicts in conducting activities in the electronic communications market, using activity tools by the public administration.

Key words: systematization of law, legal system, administrative law, legal framework, tools, implementation, consolidation. 


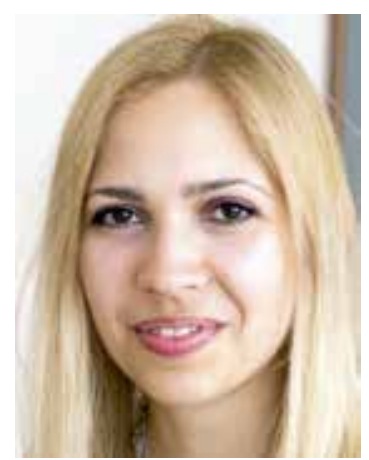

Anna Barikova, Chief Specialist of the Legal Office (I) of the Analytical and Legal Department of the Supreme Court, Ph.D in Law orcid.org/0000-0002-9707-0106 anna.barikova@gmail.com

\section{Introduction}

The main purpose of the electronic communications law systematization of, as well as any other sphere of public relations, is to optimize regulatory mechanisms in this area, as well as to create conditions for the free and effective functioning of the electronic communications market, to eliminate regulatory gaps and to prevent duplication of regulations on the content and functional purpose. Given the above, the reform of the electronic communications area is to be based on the principles of anthropocentrism, axiology and anthropology of law, existentialism considering the historical context of legal regulation formation for the state and subjects of the electronic communications market. At the same time, the basis of such systematization process should be the dogma of European law, i. e. supranational secondary law of the European Union.

The purpose of the paper is to reveal the directions of using legal provisions of the court rulings to systematize the electronic communications law in terms of consolidating legal regulations within the national legal framework of Ukraine, taking into account the supranational practice of legal support of the electronic communications market.

The electronic communications systematization issue is almost not disclosed in the domestic doctrine. Usually, researchers devote their works to the mechanism of adapting Ukrainian legislation in general to the law of the European Union (H. Aslanian, V. Denysov, L. Luts, P. Rabinovych, V. Rumiantseva, Yu. Shemshuchenko et al.). Some aspects of the legal research orientation, relegated to the idea of legislation adaptation, are revealed by such authors as A. Horbenko, I. Kravchuk, O. Tereshchenko, N. Feskov and others. In dynamic terms, the procedure of adapting the legislation of Ukraine to the standards of the European Union has been substantiated by O. Belorus, R. Lucas et al. At the same time, the mechanism of the electronic communications law systematization, which covers not only the legislation, but the secondary law of the European Union, the rules of "soft law", by-laws, etc., remains insufficiently studied, taking into account its adaptation to the European administrative law and the practice of the leading countries in this field.

2. Role of court rulings in electronic communications law systematization

Consolidation of the electronic communications law is to be carried out on a ladder of acts with equal or similar legal 
force. In the electronic communications area, according to approaches of R. Melnyk and N. Zadyraka, the relevant sources of law include: regulations of higher legal force (supranational law; the Constitution; the decision of the Constitutional Court of Ukraine; laws of Ukraine); subordinate normative regulations (enactment of the constituent public administration, entities of delegated authority); technical standards; court rulings of the highest level (Melnyk, 2017: 80-81; Hrytsenko, 2014: 100). Thus, a special place in the system of electronic communications law sources is occupied by the acts of the highest judicial authorities. In this regard, R. Melnyk notes about the "truncated" quality of such sources of law, when the law directly burdens the public administration to be guided by such acts in the activities (Melnyk, 2017: 92-93).

For example, the legal positions of the Supreme Court on implementing the institutions of the electronic communications law relate to defining legal boundaries for using tools by the public administration for engagement of electronic communications, operation of radio frequency and number resources of Ukraine and the like. Consequently, the resolution of the Supreme Court in the case № 809/340/14 dated of December 11, 2018 has established that as according to the provisions of the Law № 1770, cancellation of the permission to operation by the radio-frequency resource of Ukraine under the general rule is performed out of court on the basis of the bodies' decision defined by this law. The syntactic analysis of part 3 of the Article 58 of the Law № 1770-III should also be taken into account, indicating that the phrase "judicially" refers only to the method of collecting the sum of debt, otherwise cannot be made. Thus, the panel of judges concludes that the courts of previous instances have come to the correct conclusion that the competence of the National Commission for State Regulation in the Area of Communications and Informatization refers to the cancellation of the permit for the electronic means operation. At the same time, the receipt of information from the tax authority about the failure of the defendant to pay the fee for the radio frequency resource use is the proof of the legislation violation on use of radio frequency resource, in particular, of the Law № 1770-III which is the basis for the plaintiff's state supervision by conducting an unscheduled inspection of the defendant and not appeal to the court with the claim. In this case, the court might decide to revoke the permit only in case of refusal by the National Council of Ukraine on Television and Radio Broadcasting to take a decision within a month. In all other cases, the permit is cancelled by the National Commission for State Regulation in the Area of Communications and Informatization, or the Ukrainian State Radio Frequency Centre (Supreme Court, 2018).

Along the way, the place of the court rulings, as noted by A. Burkov, is defined due to the normative regulation place, according to which the conclusion is made (Burkov, 2002). In particular, in the electronic communications area, there are both Supreme Court rulings and a synthesis of practices, explanations and guidelines of the plenary. The first group of acts are individual in nature, but they might contain conclusions on the further practice of dealing with similar cases. The second group of acts is a superstructure over the practice of the judiciary, in addition to constitutional jurisdiction, and has traditionally defined judicial practice in the lower courts. Examples of such court rulings could be the resolution of the Plenum of the Supreme Court of Ukraine № 2 dated of March 28, 2008 "On Application Issues by the Courts of Ukraine of Legislation when Granting 
Permissions to Temporarily Restricting Certain Constitutional Rights and Freedoms of Human and Citizen during the Conduct of Operational Search Activity, Inquiry and PreTrial Investigation" (Supreme Court of Ukraine, 2008), resolution of the Supreme Court of Ukraine dated of June 5, 2012 (Supreme Court of Ukraine, 2012), etc.

It should be noted that since Soviet times, the approach has been formed, according to which the decisions of the Plenum of the Supreme Court were determined as the sources of law, and certain enactments of an individual nature were related only to judicial practice, but could not create a precedent (Isaev, 1946; Orlovskiy, 1940). On the territory of Ukraine, this approach did not experience a radical revision until 2010. Then, the Law of Ukraine "On the Judiciary and the Status of Judges" was adopted, in which paragraph 6 of part 2 of the Article 36; part 2 of the Article 38; part 2 of the Article 45 did not grant the right of the Supreme Court of Ukraine to adopt decisions of the Plenum (Verkhovna Rada of Ukraine, 2010). After this change in legislation, the Supreme Court of Ukraine has lost the opportunity to review and make amendments to existing decisions of the Plenum, in particular, in the electronic communications area. Besides, the status of previously issued regulations was left unclear regarding the validity period, action, etc. In fact, the judicial practice continued to apply the provisions of such acts. Higher specialized courts began to adopt new decisions of the Plenum, explaining the legislation (such court rulings were not adopted in the area of electronic communications). This approach is consistent with the general theoretical understanding of the succession process, according to which the previous legal provisions apply to the extent that they do not contradict the current legislation, in the absence of special requirements and the formal abolition of such legal framework (Mazur, 2011).

However, the Supreme Court of Ukraine again has actually got the right to create a precedent in 2015. It is about updating of the edition of the Article 13 of the Law of Ukraine "On the Judiciary and the Status of Judges" on the basis of the Law of Ukraine "On Ensuring the Right to a Fair Trial" (Verkhovna Rada of Ukraine, 2015). Since then, the aforementioned body of the judiciary has been competent to draw conclusions on the application of the law set out in the regulations (Verkhovna Rada of Ukraine, 2015). These enactments have become generally binding for the public administration, guided by the rules of law set out in the regulations following on from which the conclusion was made. Similarly, as a general rule, the findings of the Supreme Court set a judicial precedent for courts of general jurisdiction, except in cases of derogation from legal positions with due reasoning on the part of judges. By the way, a similar rule of law was enshrined in the Article 13 of the Law of Ukraine "On the Judiciary and the Status of Judges" № 1402-VIII dated of June 2, 2016 (Verkhovna Rada of Ukraine, 2016). Argument in favour of the described position are the provisions of part 2 of the Article 14 and part 1 of the Article 370 of the Code of Administrative Justice of Ukraine (Verkhovna Rada of Ukraine, 2005). At the same time, the acts of the highest judicial authorities in the framework of the "additional" rulemaking are mainly focused on the settlement of individual disputes, and not on the regulation of an unlimited number of such cases (Melnyk, 2017). The exception is the model cases that are heard and decided by the Supreme Court. At the same time, there have not been any such cases in the electronic communications area yet. 


\section{Pragmatics of the rule of law in the court rulings}

Moreover, a global electronic communications was the is being institutionalized in a pragmatic dimension. According to A. Pukhtetska, it is a pragmatic aspect of the concept and/or principle of the rule of law in the generalized equivalent (under the decision of the European Court of Human Rights in the case "S.W. v. the United Kingdom") (Pukhtetska, 2010). At the same time, the result of the electronic communications law consolidation is an adequate understanding of the law at the national level, consistent with the requirements of supranational regulatory frameworks. Therefore, the practice of the European Court of Human Rights (hereinafter - ECHR) plays an equally important role in the electronic communications law systematization. Influence on the implementation of legal regulations in the electronic communications area is carried out, in particular, through additions to the system of legal regulation. Examples could be considered as the ECHR'S decisions in the cases "Amann v. Switzerland" (European Court of Human Rights, 2000a), "Amuur v. France" (European Court of Human Rights, 1996) (§ 42), "Bykov v. Russia" (European Court of Human Rights, 2009a), "Copland v. the United Kingdom" (European Court of Human Rights, 2007), "Engel and others v. the Netherlands" (European Court of Human Rights, 1976: § 58), "Gaskin v. the United Kingdom" (European Court of Human Rights, 1989: § 36-37, 48), "Khan v. the United Kingdom" (European Court of Human Rights, 2009b), "Klass and others v. Germany" (European Court of Human Rights, 1978: § 41), "Labita v. Italy" (European Court of Human Rights, 2000b: $\S 170$ ), "Leander v. Sweden" (European Court of Human Rights, 1987a), "Malone v. the United Kingdom" (European Court of Human Rights, 1984), "Niemietz v. Germany" (European Court of Human Rights, 1992: § 29), "Quinn v. France" (European Court of Human Rights, 1995: § 42), "Van Vondel v. the Netherlands" (European Court of Human Rights, 2006), "Weeks v. the United Kingdom" (European Court of Human Rights, 1987b: § 40) et al.

In this regard, the legal regulations in the ECHR'S decisions play a significant role in the electronic communications law systematization primarily in the context of legal provisions dogmatization. Yu. Oborotov is convinced that such dogmatization of the law in the axiological dimension concerns the coverage of the properties of law through the rules, acts and legal relations (Oborotov, 2002: 150). Thus, the dogmas of law in the practice of the ECHR determine the characteristics, in particular, of the electronic communications law in establishing the behaviour of its subjects. That is, through logical syllogisms (the rules of law in the ECHR's practice and life circumstances), legally significant decisions of the subjects of the electronic communications market are institutionalized. Hence, the approach of the Supreme Court of Ukraine seems unjustified, according to which the ECHR's practice has a doctrinal nature and should be applied in Ukraine only via translated into Ukrainian and officially published ECHR'S decisions (Supreme Court of Ukraine, 2016). Artificial narrowing of the scope of supranational law of the European Union, notably the ECHR's practice, does not correspond to the idea of the rule of law. In addition, this source of law has an applied nature, and therefore could not be considered as a category of doctrinal postulates.

In fact, through the dogmas in the ECHR's practice legal values in instrumental and content dimensions are transferred to the electronic communications law. The 
provisions of the ECHR's practice at the same time provide stability, integration and coordination of the electronic communications law through the impact on its systemstructural dimension, security, communication, cognitive, heuristic and other functions. In addition, these dogmas have a dynamic nature, creating conditions for the provision of fundamental human values in the activities of subjects of the electronic communications market, as well as for the removal of social tension. Along the way, the change in social circumstances leads to an update of the content of the dogmas presented in the ECHR's practice. Such process becomes possible through the instrumental nature of the supranational law of the European Union as the basis for the electronic communications law systematization. The functional social and technological aspect of values is revealed in the provisions of the electronic communications law, and through the latter - in the activities of the subjects of the electronic communications market.

As O. Sydorenko points out, thanks to the dogmatic methodology, it becomes possible to create, apply and process the rule of law (Sydorenko, 2014). In particular, in the electronic communications law, the dogmatic dimension of the ECHR's practice primarily concerns the interpretation of regulations and the filling of legal gaps. As a rule, the methods of analysis and synthesis, analogy, presumption, casuistry are used. Through linguistic and grammatical interpretation of the provisions of the legislation, by-laws and technical regulations, the ECHR ensures harmonization of the electronic communications law through epistemological procedures. This interpretation determines the context of practical implementation of the electronic communications law. The casuistic methodology is needed for hypothetical coverage of different views on the situation regarding the disputed, unrecognized or violated rights and legitimate interests of the subjects of the electronic communications market.

In fact, the provisions of the ECHR's practice as a dogma of the electronic communications law might have an impact on the law not only regarding the definition of the essence of certain types of regulations, the system of the electronic communications law, but also on the implementation of legal regulation in this area. This contributes to the implementation of the European approaches in this field. In this context, R. Melnyk focuses on the system of law that has two levels: "basic" and "current". Within the framework of the "basic" level, there are rules of law, crystallized throughout the civilizational development of society, which objectively exist and act separately from extraneous factors, the will of individuals and are reflected in the principles of law (the basis for the formation of the "current" level and the objective factor of the European integration process). The content component of the "current" level is determined by the level of legal awareness, culture of society, forms of state, law-making activity (Melnyk, 2012: 11-12). That is why, in the context of the European integration processes, it is appropriate to formulate court rulings in the electronic communications area in such a way as to make allowance for the fundamental principles of the ECHR's practice in the aspect of reducing, and in the future - eliminating the gap between the "basic" and "current" levels of the electronic communications law system in Ukraine. This proposal could be implemented by taking into account the criteria for understanding the essence of the categories "rule of law", "law", "legal" and the like, as well as the "basic" level of the electronic communications law system. 


\section{ОСОБЛИВЕ АДМІНІСТРАТИВНЕ ПРАВО}

\section{Conclusions}

Therefore, in order to ensure equal relations between the public administration, subjects of the electronic communications market and consumers (users, subscribers), it is necessary to heed primarily the ECHR's practice and national supreme judicial authorities' rulings. It seems appropriate to implement legal positions of the judiciary, which will contribute to the institutionalization of the rule of law in functioning of the electronic communications market. Thus, the decisions of the Supreme Court could provide insights regarding the future of the practice of similar cases consideration. Generalization of practices, explanations and guidelines of the Plenum is a superstructure that defines the judicial practice in the lower instances in order to resolve conflicts in implementing activities in the electronic communications market of, using the tools by the public administration. Based on the European experience of regulating relations in the electronic communications area, it is to be noted that the Ukrainian legislation needs to be amended in the context of a harmonized regulatory framework for all electronic communication networks and services.

\section{Bibliography:}

1. 100 ответов на 100 вопросов по Общему административному праву : учебное пособие / под ред. Р.С. Мельника. Киев : Юринком Интер, 2017. 240 с.

2. Бурков А.Л. Акты правосудия как источники административного права : автореф. дисс. ... канд. юрид. наук : 12.00 .14 ; Уральская государственная юридическая академия. Екатеринбург, 2002. 20 c.

3. Исаев М.М. В секторе судебного права Института права Академии наук СССР. Советское государство и право. 1946. № 10. С. 41-43.

4. Загальне адміністративне право : підручник / за заг. ред. І.С. Гриценка. Київ : Юрінком Інтер, 2014. $568 \mathrm{c}$.

5. Кодекс адміністративного судочинства України : Закон України від 6 липня 2005 p. № 2747-IV (зі змінами і доповненнями станом на 14 червня 2018 р.) / Верховна Рада України. Відомості Верховної Ради Украӥни. 2005. № 35-37. Ст. 446.

6. Мазур М.В. Місце роз'яснень Пленуму Верховного Суду України в системі джерел права України: минуле та сучасність. Ученые записки Таврического нащионального университета имени В.И. Вернадского. Серия «Юридические науки». 2011. Т. 24 (63). № 1. С. 3-12.

7. Мельник Р.С. Що розуміти під категорією «система права»? Адміністративне право i прочес. 2012. № 1(1). С. 10-16.

8. Оборотов Ю.Н. Традиции и обновление в правовой сфере: вопросы теории (от познания к постижению права). Одесса : Юридическая литература, 2002. 280 с.

9. Орловский П.Е. Значение судебной практики в развитии советского гражданского права. Советское государство и право. 1940. № 8-9. С. 91-97.

10. Постанова Верховного Суду України від 24 квітня 2012 р. у справі № 21-35a12 / Верховний Суд України. URL: http://www.reyestr.court.gov.ua/Review/24976406 (дата звернення: 28.12.2018).

11. Постанова Верховного Суду від 11 грудня 2018 р. у справі № 809/340/14 / Верховний Суд України. URL: http://www.reyestr.court.gov.ua/Review/78528278 (дата звернення: 28.12.2018).

12. Про деякі питання застосування судами України законодавства при дачі дозволів на тимчасове обмеження окремих конституційних прав і свобод людини і громадянина під час здійснення оперативно-розшукової діяльності, дізнання і досудового слідства : Постанова 
Пленуму Верховного Суду України від 28 березня 2008 р. № 2 (зі змінами і доповненнями станом на 4 червня 2010 р.) / Верховний Суд України. Вісник Верховного Суду Украӥни. 2008. № 4. C. 4.

13. Про забезпечення права на справедливий суд : Закон України від 12 лютого 2015 р. № 192-VIII (зі змінами і доповненнями станом на 30 вересня 2016 р.) / Верховна Рада України. Відомості Верховної Ради України. 2015. № 18-20. Ст. 132.

14. Про судоустрій і статус суддів : Закон України від 7 липня 2010 р. № 2453-VI (втратив чинність 30 вересня 2016 р.) / Верховна Рада України. Відомості Верховної Ради України. 2010. № 41-45. Ст. 529.

15. Про судоустрій і статус суддів : Закон України від 2 червня 2016 р. № 1402-VIII (зі змінами і доповненнями станом на 5 серпня 2018 р.) / Верховна Рада України. Відомості Верховної Ради України. 2016. № 31. Ст. 545.

16. Пухтецька А.А. Принцип верховенства права: сучасні європейські доктрини як орієнтир для реформування національного законодавства. Вісник Національної академії наук України. 2010. № 3. С. 33-43.

17. Сидоренко О.М. Догма права у контексті юридичної діяльності. Науковий вісник Міжнародногогуманітарного університету. Серія «Юриспруденція». 2014. Вип. 7. С. 54-57.

18. Справа «Класс та інші проти Німеччини» : Рішення Європейського суду 3 прав людини від 6 вересня 1978 р. / Європейський суд 3 прав людини. URL: http://zakon3.rada.gov.ua/laws/show/980093 (дата звернення: 28.12.2018).

19. Ухвала Верховного Суду України від 21 квітня 2016 р. у справі № 6-756ц16 / Верховний Суд України. URL: http://www.reyestr.court.gov.ua/Review/57345903 (дата звернення: 28.12.2018).

20. Case of Amann v. Switzerland / European Court of Human Rights. URL: https://www.legal-tools.org/doc/6e49ed/pdf/ (access date: 28.12.2018).

21. Case of Amuur v. France / European Court of Human Rights. URL: http://www.asylumlawdatabase.eu/sites/www.asylumlawdatabase.eu/files/aldfiles/CASE\%20 OF\%20AMUUR\%20v.\%20FRANCE.pdf (access date: 28.12.2018).

22. Case of Bykov v. Russia / European Court of Human Rights. URL: https://www.legaltools.org/doc/389d4b/pdf/ (access date: 28.12.2018).

23. Case of Copland v. the United Kingdom / European Court of Human Rights. URL: http://www.juridice.ro/wp-content/uploads/2016/07/1531450.pdf (access date: 28.12.2018).

24. Case of Engel and others v. the Netherlands / European Court of Human Rights. URL: https://www.legal-tools.org/doc/6bfadc/pdf/ (access date: 28.12.2018).

25. Case of Gaskin v. the United Kingdom / European Court of Human Rights. URL: http://www.juridischeuitspraken.nl/19890707EHRMGaskin.pdf (access date: 28.12.2018).

26. Case of Khan v. the United Kingdom / European Court of Human Rights. URL: https://www.legal-tools.org/doc/a05669/pdf/ (access date: 28.12.2018).

27. Case of Labita v. Italy / European Court of Human Rights. URL: https://www.legal-tools.org/ $\mathrm{doc} / \mathrm{dccaed} / \mathrm{pdf} /$ (access date: 28.12.2018).

28. Case of Leander v. Sweden / European Court of Human Rights. URL: https://www.legal-tools.org/doc/a5ab8b/pdf/ (access date: 28.12.2018).

29. Case of Malone v. the United Kingdom / European Court of Human Rights. URL: https://www.legal-tools.org/doc/8985ce/pdf/ (access date: 28.12.2018).

30. Case of Niemietz v. Germany / European Court of Human Rights. URL: http://www.worldlii.org/eu/cases/ECHR/1992/80.html (access date: 28.12.2018).

31. Case of Quinn v. France / European Court of Human Rights. URL: http://www.menschenrechte.ac.at/orig/95_2/Quinn.pdf (access date: 28.12.2018). 


\section{ОСОБЛИВЕ АДМІНІСТРАТИВНЕ ПРАВО}

32. Case of Van Vondel v. the Netherlands / European Court of Human Rights. URL: https://www.hr-dp.org/files/2013/09/11/CASE_OF_VAN_VONDEL_v._THE_ NETHERLANDS_.pdf (access date: 28.12.2018).

33. Case of Weeks v. the United Kingdom / European Court of Human Rights. URL: https://www.legal-tools.org/uploads/txltpdb/CASEOFWEEKSv.THEUNITEDKINGDOM ARTICLE50.pdf (access date: 28.12.2018).

\section{References:}

1. Melnik, R.S. (2017). 100 otvetov na 100 voprosov po Obshchemu administrativnomu pravu: uchebnoe posobie [100 answers to 100 questions on General administrative law: tutorial]. Kyiv: Iurinkom Inter [in Russian].

2. Burkov, A.L. (2002). Akty pravosudiia kak istochniki administrativnogo prava [Acts of justice as sources of administrative law] (Extended abstract of candidate's thesis). Ekaterinburg: Ural State Law Academy [in Russian].

3. Isaev, M.M. (1946). V sektore sudebnogo prava Instituta prava Akademii nauk SSSR [In the Sector of Judicial Law of the Institute of Law of the Academy of Sciences of the USSR]. Sovetskoe gosudarstvo i pravo, no. 10, pp. 41-43 [in Russian].

4. Hrytsenko, I.S. (ed.) (2014). Zahalne administratyvne pravo: pidruchnyk [General administrative law: textbook]. Kyiv: Yurinkom Inter [in Ukrainian].

5. Verkhovna Rada of Ukraine. (2005). Kodeks administratyvnoho sudochynstva Ukrainy: Zakon Ukrainy vid 6 lypnia 2005 r. № 2747-IV (zi zminamy i dopovnenniamy stanom na 14 chervnia 2018 r.) [Code of Administrative Justice of Ukraine: Law of Ukraine dated July 6, 2005 № 2747-IV (with amendments and additions as of June 14, 2018)]. Vidomosti Verkhovnoi Rady Ukrainy, no. 35-37, art. 446 [in Ukrainian].

6. Mazur, M.V. (2011). Mistse roziasnen Plenumu Verkhovnoho Sudu Ukrainy v systemi dzherel prava Ukrainy: mynule ta suchasnist [Place of explanations of the Plenum of the Supreme Court of Ukraine in the system of sources of law in Ukraine: past and present]. Uchenye zapiski Tavricheskogo natsionalnogo universiteta imeni V.I. Vernadskogo. Seriia "Iuridicheskie nauki", vol. 24(63), no. 1, pp. 3-12 [in Ukrainian].

7. Melnyk, R.S. (2012). Shcho rozumity pid katehoriieiu "systema prava"? [What is to be meant by the "system of law" category?]. Administratyvne pravo i protses, no. 1(1), pp. 10-16 [in Ukrainian].

8. Oborotov, Iu.N. (2002). Traditsii $i$ obnovlenie v pravovoi sfere: voprosy teorii (ot poznaniia $k$ postizheniiu prava) [Traditions and renewal in the legal sphere: theoretical issues (from cognition to comprehension of law)]. Odessa: Iuridicheskaia literatura [in Russian].

9. Orlovskii, P.E. (1940). Znachenie sudebnoi praktiki v razvitii sovetskogo grazhdanskogo prava [The value of judicial practice in the development of Soviet civil law]. Sovetskoe gosudarstvo i pravo, no. 8-9, pp. 91-97 [in Russian].

10. Supreme Court of Ukraine. (2012). Postanova Verkhovnoho Sudu Ukrainy vid 24 kvitnia 2012 r. u spravi № 21-35a12 [Resolution of the Supreme Court of Ukraine dated April 24, 2012 in case № 21-35a12]. Retrieved from: http://www.reyestr.court.gov.ua/Review/24976406 [in Ukrainian].

11. Supreme Court. (2018). Postanova Verkhovnoho Sudu vid 11 hrudnia 2018 r. u spravi № 809/340/14 [Resolution of the Supreme Court on 11 December 2018 in case № 809/340/14]. Retrieved from: http://www.reyestr.court.gov.ua/Review/78528278 [in Ukrainian].

12. Supreme Court of Ukraine. (2008). Pro deiaki pytannia zastosuvannia sudamy Ukrainy zakonodavstva pry dachi dozvoliv na tymchasove obmezhennia okremykh konstytutsiinykh prav i svobod liudyny i hromadianyna pid chas zdiisnennia operatyvno-rozshukovoi diialnosti, 
diznannia i dosudovoho slidstva: Postanova Plenumu Verkhovnoho Sudu Ukrainy vid 28 bereznia 2008 r. № 2 (zi zminamy i dopovnenniamy stanom na 4 chervnia 2010 r.) [On some issues of application by the courts of Ukraine of legislation when granting permissions for a temporary limitation of certain constitutional rights and freedoms of man and citizen during the conduct of operational-search activity, inquiry and pre-trial investigation: Resolution of the Plenum of the Supreme Court of Ukraine dated March 28, 2008 № 2 (as amended and supplements as of June 4, 2010)]. Visnyk Verkhovnoho Sudu Ukrainy, no. 4, pp. 4 [in Ukrainian].

13. Verkhovna Rada of Ukraine. (2015). Pro zabezpechennia prava na spravedlyvyi sud: Zakon Ukrainy vid 12 liutoho 2015 r. № 192-VIII (zi zminamy i dopovnenniamy stanom na 30 veresnia 2016 r.) [On ensuring the right to a fair trial: Law of Ukraine dated February 12, 2015, № 192-VIII (with amendments and additions as of September 30, 2016)]. Vidomosti Verkhovnoi Rady Ukrainy, no. 18-20, art. 132 [in Ukrainian].

14. Verkhovna Rada of Ukraine. (2010). Pro sudoustrii i status suddiv: Zakon Ukrainy vid 7 lypnia 2010 r. № 2453-VI (vtratyv chynnist 30 veresnia 2016 r.) [On the Judiciary and the Status of Judges: Law of Ukraine dated July 7, 2010 № 2453-VI (expired September 30, 2016)]. Vidomosti Verkhovnoi Rady Ukrainy, no. 41-45, art. 529 [in Ukrainian].

15. Verkhovna Rada of Ukraine. (2016). Pro sudoustrii i status suddiv: Zakon Ukrainy vid 2 chervnia 2016 r. № 1402-VIII (zi zminamy i dopovnenniamy stanom na 5 serpnia 2018 r.) [On the Judicial System and Status of Judges: Law of Ukraine dated June 2, 2016 № 1402-VIII (with amendments and additions as of August 5, 2018)]. Vidomosti Verkhovnoi Rady Ukrainy, no. 31, art. 545 [in Ukrainian].

16. Pukhtetska, A.A. (2010). Pryntsyp verkhovenstva prava: suchasni yevropeiski doktryny yak oriientyr dlia reformuvannia natsionalnoho zakonodavstva [Principle of the rule of law: modern European doctrines as a benchmark for reforming national legislation]. Visnyk Natsionalnoi akademii nauk Ukrainy, no. 3, pp. 33-43 [in Ukrainian].

17. Sydorenko, O.M. (2014). Dohma prava u konteksti yurydychnoi diialnosti [The dogma of law in the context of legal activity]. Naukovyi visnyk Mizhnarodnoho humanitarnoho universytetu. Seriia "Yurysprudentsiia", issue 7, pp. 54-57 [in Ukrainian].

18. European Court of Human Rights (1978). Sprava "Klass ta inshi proty Nimechchyny": Rishennia Yevropeiskoho sudu z prav liudyny vid 6 veresnia 1978 r. [Case "Klass and others v. Germany": Judgment of the European Court of Human Rights dated September 6, 1978]. Retrieved from: http://zakon3.rada.gov.ua/laws/show/980093 [in Ukrainian].

19. Supreme Court of Ukraine. (2016). Ukhvala Verkhovnoho Sudu Ukrainy vid 21 kvitnia 2016 r. u spravi № 6-756ц16 [Decision of the Supreme Court of Ukraine dated April 21, 2016 in the case № 6-756ц16]. Retrieved from: http://www.reyestr.court.gov.ua/Review/57345903 [in Ukrainian].

20. European Court of Human Rights (2000a). Case of Amann v. Switzerland. Retrieved from: https://www.legal-tools.org/doc/6e49ed/pdf/ [in English].

21. European Court of Human Rights (1996). Case of Amuur v. France. Retrieved from: http://www.asylumlawdatabase.eu/sites/www.asylumlawdatabase.eu/files/aldfiles/CASE\%20 OF\%20AMUUR\%20v.\%20FRANCE.pdf [in English].

22. European Court of Human Rights (2009a). Case of Bykov v. Russia. Retrieved from: https://www.legal-tools.org/doc/389d4b/pdf/ [in English].

23. European Court of Human Rights (2007). Case of Copland v. the United Kingdom. Retrieved from: http://www.juridice.ro/wp-content/uploads/2016/07/1531450.pdf [in English]

24. European Court of Human Rights (1976). Case of Engel and others v. the Netherlands. Retrieved from: https://www.legal-tools.org/doc/6bfadc/pdf/ [in English].

25. European Court of Human Rights (1989). Case of Gaskin v. the United Kingdom. Retrieved from: http://www.juridischeuitspraken.nl/19890707EHRMGaskin.pdf [in English]. 


\title{
ОСОБЛИВЕ АДМІНІСТРАТИВНЕ ПРАВО
}

26. European Court of Human Rights (2009b). Case of Khan v. the United Kingdom. Retrieved from: https://www.legal-tools.org/doc/a05669/pdf/ [in English].

27. European Court of Human Rights (2000b). Case of Labita v. Italy. Retrieved from: //www.legal-tools.org/doc/dccaed/pdf/ [in English].

28. European Court of Human Rights (1987a). Case of Leander v. Sweden. Retrieved from: https://www.legal-tools.org/doc/a5ab8b/pdf/ [in English].

29. European Court of Human Rights (1984). Case of Malone v. the United Kingdom. Retrieved from: https://www.legal-tools.org/doc/8985ce/pdf/ [in English].

30. European Court of Human Rights (1992). Case of Niemietz v. Germany. Retrieved from: http://www.worldlii.org/eu/cases/ECHR/1992/80.html [in English].

31. European Court of Human Rights (1995). Case of Quinn v. France. Retrieved from: http://www.menschenrechte.ac.at/orig/95_2/Quinn.pdf [in English].

32. European Court of Human Rights (2006). Case of Van Vondel v. the Netherlands. Retrieved from: https://www.hr-dp.org/files/2013/09/11/CASE_OF_VAN_VONDEL_v._THE_ NETHERLANDS_.pdf [in English].

33. European Court of Human Rights (1987b). Case of Weeks v. the United Kingdom. Retrieved from: https://www.legal-tools.org/uploads/txltpdb/CASEOFWEEKSv.THEUNITED KINGDOMARTICLE50.pdf [in English].

\section{ВПЛИВ АКТІВ ОРГАНІВ СУДОВОЇ ВЛАДИ НА СИСТЕМАТИЗАЦЮЮ ПРАВА ЕЛЕКТРОННИХ КОМУНІКАЦІЙ}

\author{
Анна Барікова, \\ головний спеціаліст правового управління (I) \\ департаменту аналітичної та правової роботи Верховного Суду, \\ кандидат юридичних наук \\ orcid.org/0000-0002-9707-0106 \\ anna.barikova@gmail.com
}

Мета. Стаття розкриває напрями використання правових позицій актів органів судової влади для систематизації права електронних комунікацій у частині консолідації юридичних норм у межах національної правової бази України з урахуванням наднаціональної практики правового забезпечення діяльності учасників ринку електронних комунікацій.

Методи. Для досягнення цілей дослідження автор використовує спеціально-юридичні методи наукового пізнання: формально-логічниц̆, системно-функціональний, порівняльно-правовий.

Результати. У першій частині статті автор розглядає місие актів органів судової влади в системі актів, згідно з якими повинна проводитися консолідація норм права електронних комунікацій. 3 урахуванням новітніх доктринальних підходів уточнено "усічену» якість цих джерел права. Автор наводить приклади того, як правові позичї Верховного Суду стосуються визначення законних меж використання інструментів діяльності публічної адміністрації щзодо використання електронних комунікацій, експлуатації радіочастотного та номерного ресурсів України тощо.

Друга частина статті підтверджує думку, щุо положення практики Свропейського суду з прав людини можуть спричиняти вплив не лише на право електронних комунікацій щцодо визначення сутності окремих видів актів законодавства та 
системи права електронних комунікацій, а й на порядок реалізації правового регулювання в иій сфері. Продемонстровано роль практики Європейського суду з прав людини в систематизації права електронних комунікацій у контексті догматизації юридичних норм.

Висновки. На підставі аналізу європейських і національних актів органів судової влади автор доходить висновку, щзо доиільною є імплементація тих правових позицій органів судової влади, які сприятимуть інституичіоналізації приничиу верховенства права під час функціонування ринку електронних комунікацій. Також доведено, щцо в постановах Верховного Суду можуть міститися висновки щодо подальшої практики розгляду аналогічних справ. Узагальнення практики, роз'яснення та керівні вказівки Пленуму Верховного Суду є надбудовою, яка визначає судову практику в нижчих інстанціях із метою розв'язання конфліктів під час провадження діяльності на ринку електронних комунікацій та використання інструментів діяльності суб'єктів публічної адміністрації.

Ключові слова: систематизація права, правова система, адміністративне право, правовий механізм, інструменти, імплементація, консолідація. 